\title{
POPULATION DYNAMICS OF TUNA (EUTHYNNUS AFFINIS, CANTOR 1849) IN WESTERN WATERS OF SOUTH SULAWESI
}

\author{
Budiman Yunus ${ }^{* 1}$ 瓜, Suwarni ${ }^{1}$, Basse Siang Parawansa ${ }^{1}$ \\ ${ }^{* 1}$ Department of Fisheries, Faculty of Marine Science and Fisheries, Hasanuddin University, \\ Indonesia
}

DOI: https://doi.org/10.29121/granthaalayah.v8.i8.2020.1001

Article Type: Research Article

Article Citation: Budiman Yunus, Suwarni, and Basse Siang Parawansa. (2020). POPULATION DYNAMICS OF TUNA (EUTHYNNUS AFFINIS, CANTOR 1849) IN WESTERN WATERS OF SOUTH SULAWESI. International Journal of Research -GRANTHAALAYAH, 8(8), 164-172.

https://doi.org/10.29121/granthaa layah.v8.i8.2020.1001

Received Date: 06 August 2020

Accepted Date: 22 August 2020

Keywords:

Tuna

Growth Coefficient

Asymptote Length

Mortality

Exploitation

Yield Per Recruitment

\section{ABSTRACT}

This study aims to determine the population dynamics of tuna including age group, growth, mortality, exploitation rate and yield per recruitment. It was conducted from June to August in West Waters of South Sulawesi. By method of age group using Bhattacharya method with FAOICLARM Fish Stock Assessment Tools II (FISAT II) program, growth using Von Bertalanffy's equation, natural mortality (M) using Pauly's empirical equation, total mortality $(\mathrm{Z})$ using Beverton and Holt's equations, fishing mortality (F) by the formula $\mathrm{Z}=\mathrm{F}+\mathrm{M}$, exploitation (E) using Baverton and Holt's equations and yield per recruitment (Y/R') using Baverton and Holt's equations. The results of research of tuna observed were 737 includes 355 male tunas and 382 female tunas. The estimation of total length ranging from $215 \mathrm{~mm}$ to $429 \mathrm{~mm}$. Male tunas are classified into 4 (four) of age groups with a length of 236.67, 272.8, 326.04 and $375.53 \mathrm{~mm}$, respectively. Asymptote length $(\mathrm{L} \infty)=455.00 \mathrm{~mm}$, growth coefficient $(\mathrm{K})=0.33$ and theoretical age $(\mathrm{t} 0)$ of -0.2377 per year. Total mortality rate $(\mathrm{Z})=1.12$ per year. Natural mortality $(\mathrm{M})=0.41$ per year, fishing mortality $(\mathrm{F})=0.71$, exploitation $(E)=0.63$ and yield per recruitment $\left(Y / R^{\prime}\right)=0.0691$, while male tunas are classified into 5 (five) of age groups with a length of 235.73, 272.86, 326.89, 360.89 and $408.89 \mathrm{~mm}$, respectively. Asymptote length $(\mathrm{L} \infty)=453.50 \mathrm{~mm}$, growth coefficient $(\mathrm{K})=0.42$ and theoretical age $(\mathrm{t} 0)$ of -0.1853 per year. Total mortality rate $(Z)=1.35$ per year. Natural mortality $(\mathrm{M})=0.48$ per year, fishing mortality $(\mathrm{F})=0.87$, exploitation $(\mathrm{E})=0.64$ and yield per recruitment $\left(\mathrm{Y} / \mathrm{R}^{\prime}\right)=0.0784$. Thus, it can be concluded that tuna in West Waters of South Sulawesi have declined and thought occur overfishing.

\section{INTRODUCTION}

Pelagic fish production in the western waters of South Sulawesi reaches 55.6\%. The percentage of production indicates the availability of pelagic fish in the West Waters of South Sulawesi is greater than other coastal waters in South Sulawesi (Nelwan, 2010). One of pelagic fishes found in the western waters of South Sulawesi which has high economic value is tuna, because the level of market demand is increasing every year. This because tuna fish is much favored by the community, especially those in Lero village of Pinrang district so that this fish is one of the fisheries that are targeted by fishermen. 
According to statistics from the Marine and Fisheries Office of Pinrang (2017), it shows that the production of tuna in Pinrang has increased from year to year. In 2014, tuna production was 223 tons, in 2015 it was 931 tons, and in 2016 there was an increase in production reaching 965 tons. Based on these data, it can be seen that the production of tuna during the last 3 years, namely in 2014 - 2016 in Pinrang district experienced a significant increase, it because the fishing rate of tuna is getting higher.

For the potential of tuna in Western Waters of South Sulawesi can be utilized optimally, sustainably and avoid overfishing, a study on population dynamics can be used as a reference in the development of fisheries resource management, so that the intended utilization of fisheries resources can be realized.

This study aims to determine some dynamic parameters of tuna population including age group, growth rate, mortality, exploitation rate and yield per recruitment (Y/R) in Western Waters of South Sulawesi.

The benefit of study is to provide information about tuna in Western waters of South Sulawesi and it can be a consideration in planning and management of tuna, to realize optimal and sustainable use of resources and can be used as information material for further research.

\section{METHOD OF RESEARCH}

This study was conducted in June 2019 until August 2019. Sampling of sample fish was carried out in the waters of Makassar Strait, Pinrang district of South Sulawesi (Figure 1).

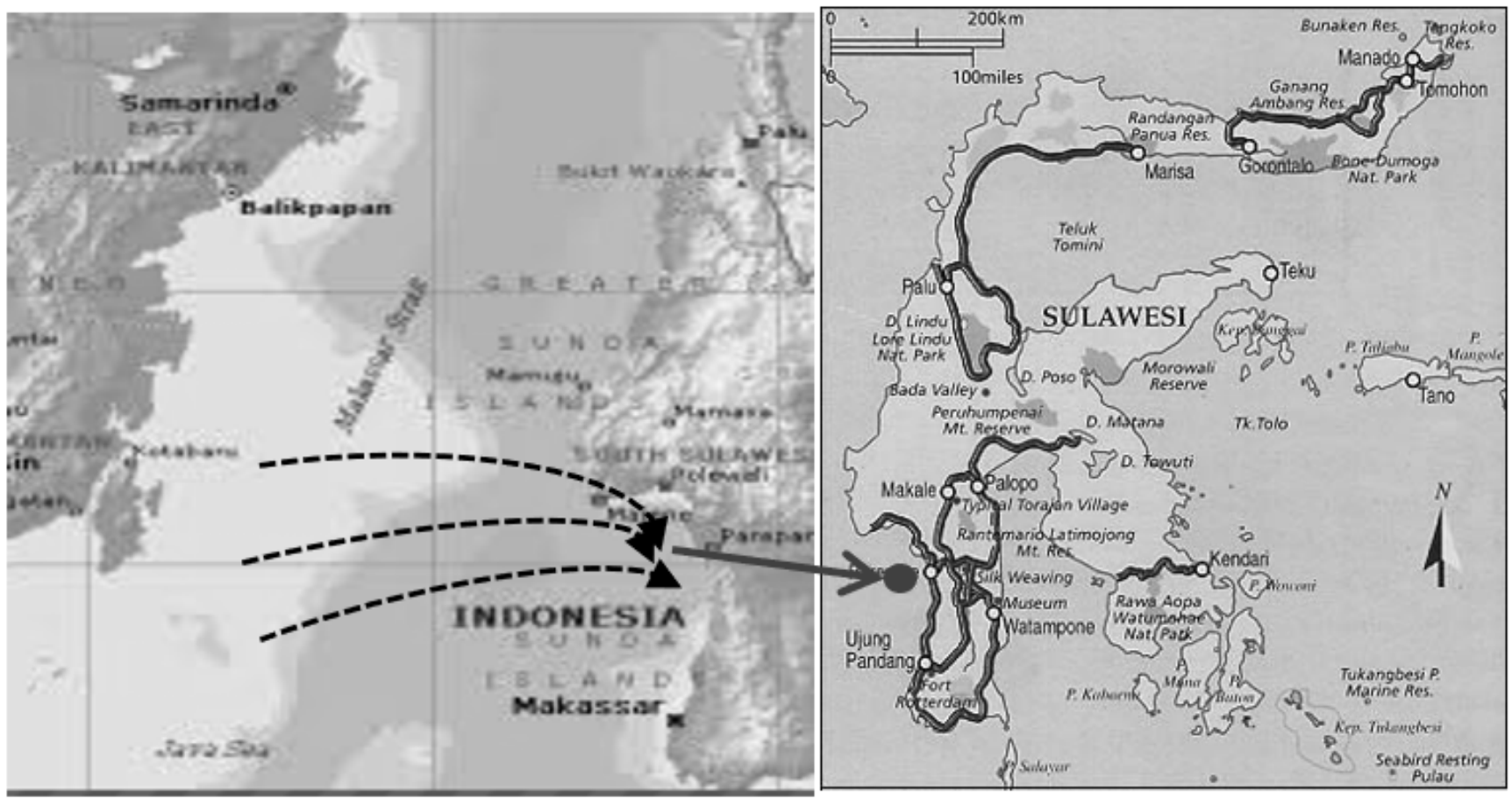

Figure 1: Map of research site in Western Waters of South Sulawesi, Makassar Strait

\subsection{TOOLS AND MATERIALS}

The tools used was a measuring ruler with a precision of $0.1 \mathrm{~cm}$ to measure the total length of fish body, stationery used to write research data in the field, surgical instruments to dissect the fish and a camera for documentation of activities in the field.

The material used was tuna obtained from the Western Waters of South Sulawesi as a research sample.

\subsection{COLLECTING SAMPLE FISH}

Sampling of tuna comes from overall catch of fishermen every day in the Western Waters of South Sulawesi (Figure 1) 
The fishing gear used by fishermen is fishing line. Sampling was done every day during June to August 2019. Furthermore, the fish samples were taken to measure the total body length starting from the front end of the head to the tip of the caudal end using a ruler in $0.1 \mathrm{~cm}$ precision. Then, the fish is dissected and the gonads are observed to determine their sex, based on the color and the average temperature data of Western Waters of Sulawesi South obtained from the Meteorology, Climatology, and Geophysical Agency of Makassar.

\subsection{AGE GROUP}

The age group is determined by using Bhattacharya's method with FAO-ICLARM Fish Stock Assessment Tools II (FISAT II) program. The first, the procedure for determining age groups is determine the class length, frequency and middle class. The number of cohorts, and the average length of individuals in each age group were obtained by using a long frequency difference, i.e fish were divided into long classes which then find the difference between the highest and lowest values of a class with the previous class. One age group (cohort) is characterized by a histogram that increase and then decreases. Age groups are obtained by analyzing long data which are then classified into several classes (Sari, 2013).

\subsection{GROWTH}

Growth rates related to fish length follow Von Bertalanffy's growth equation (Sparre and Venema, 1999), as follows:

$\mathrm{L}_{\mathrm{t}}=\mathrm{L}^{\infty}(1-\mathrm{e}[-\mathrm{K}(\mathrm{t}-\mathrm{t} 0)])$

Where:

$\mathrm{Lt}=$ length of fish at age $t(\mathrm{~mm})$

$\mathrm{L} \infty=$ theoretical maximum length $(\mathrm{mm})$

$\mathrm{K}=$ growth coefficient (year)

$\mathrm{t}_{0}=$ theoretical age at length equal to zero (years)

$\mathrm{t}=$ age (years)

Methods for determining the asymptote length $\left(\mathrm{L}^{\infty}\right)$ and growth coefficient $(\mathrm{K})$ were estimated by using ELEFAN I subprogram contained in FISAT II software package (Gayanilo et al., 2005). The theoretical age ( $\mathrm{t}_{0}$ ) is estimated by using the Pauly's (1983) formula as follows:

$\log \left(-\mathrm{t}_{0}\right)=0,3922-0,2752\left(\log \mathrm{L}^{\infty}\right)-1,038(\log \mathrm{K})$

\subsection{MORTALITY AND EXPLOITATION RATE}

\subsubsection{TOTAL MORTALITY}

Total mortality $(\mathrm{Z})$ is conducted by using the length converted catch curve method in the FISAT II program (Pauly, 1983, Gayanilo et al., 2005, Ongkers, 2006) as follows:

$$
Z=\frac{Z_{j}+Z_{i+1}}{2}
$$

Where:

$\mathrm{Z}=$ total mortality (per year)

\subsubsection{NATURAL MORTALITY}

The natural mortality rate (M) was estimated by Pauly's equation (1983) using data on the average temperature of the Western Waters of South Sulawesi in year (T) 2017 (BMKG, 2017) with the following formula:

$\log (M)=-0.0066-0.279 \log \operatorname{L} \infty+0.6543 \log K+0.4634 \log T$

Where:

$\mathrm{M}=$ natural mortality rate (per year)

$\mathrm{L} \infty=$ asymptote length of fish $(\mathrm{mm})$

International Journal of Research -GRANTHAALAYAH 
$\mathrm{K}=$ growth coefficient (year)

$\mathrm{T}=$ average temperature of Western Water of South Sulawesi $29^{\circ} \mathrm{C}$

\subsubsection{FISHING MORTALITY}

Fishing Mortality Rate (F) is estimated by using the formula:

$\mathrm{Z}=\mathrm{F}+\mathrm{M}$

So, it can be obtained:

$\mathrm{F}=\mathrm{Z}-\mathrm{M}$

Where:

$\mathrm{F}=$ fishing mortality (per year)

$\mathrm{Z}=$ total mortality rate (per year)

$\mathrm{M}=$ natural mortality (per year)

\subsubsection{EXPLOITATION RATE}

Exploitation rate (E) is assumed by using Beverton and Holt's equations (Sparre and Vanema, 1999) as follows: $\mathrm{E}=\mathrm{F} / \mathrm{Z}$

Where:

$\mathrm{F}=$ fishing mortality (per year)

$\mathrm{Z}=$ total mortality rate (per year)

$\mathrm{M}=$ natural mortality (per year)

$\mathrm{E}=$ exploitation rate (per year)

\subsection{YIELD PER RECRUITMENT}

It obtained by using Baverton and Holt's equations (Sparre and Vanema, 1999), as follows:

$$
\begin{aligned}
& Y / R=E \cdot U^{M / K}\left(1-\frac{3 U}{1+m}+\frac{3 U^{2}}{1+2 m}-\frac{U^{3}}{1+3 m}\right) \\
& \text { dimana : } U=1-\frac{L^{\prime}}{L \propto} \quad ; \quad m=\frac{1-E}{M / K}
\end{aligned}
$$

Where:

$M=$ natural mortality (per year)

$L^{\prime}=$ the smallest size limit of full length of fish caught $(\mathrm{mm})$

$\mathrm{L} \infty=$ asymptote length of fish (mm)

$\mathrm{K}=$ growth rate coefficient (per year)

$\mathrm{E}=$ exploitation rate (per year)

\section{RESULTS AND DISCUSSION}

Total sample of tuna obtained during the study was 737 consisting of 355 male tunas and 382 female tunas. The length of male tuna ranging from is $224 \mathrm{~mm}-429 \mathrm{~mm}$ with the highest frequency of length is $272-275 \mathrm{~mm}$ by 34 while the length of female tuna ranging from $215 \mathrm{~mm}-428 \mathrm{~mm}$ with the highest frequency of length is $271-274$ $\mathrm{mm}$ by 34 . The lengths of male tunas are classified into 52 classes and 54 female tunas with each using interval 4.

\subsection{AGE GROUP (COHORT)} 1.

Age group of tuna fish uses length frequency distribution analysis. The age group of tuna is presented in Figure 
In Figure 1 indicates the age group of tuna (Euthynnus affinis), male tuna has 4 (four) age groups, with an average length of the first group of $236.67 \mathrm{~mm}$, the second group of $272.8 \mathrm{~mm}$, the third group of $326.04 \mathrm{~mm}$ and the fourth group of 375.53 and the female tuna have 5 (five) age groups, with an average length of the first group of $235.73 \mathrm{~mm}$, the second group of $272.86 \mathrm{~mm}$, the third group of $328.89 \mathrm{~mm}$, the fourth group of 360.89 and the fifth group of 408.89. The results of analysis of each groups are listed in Table 1.

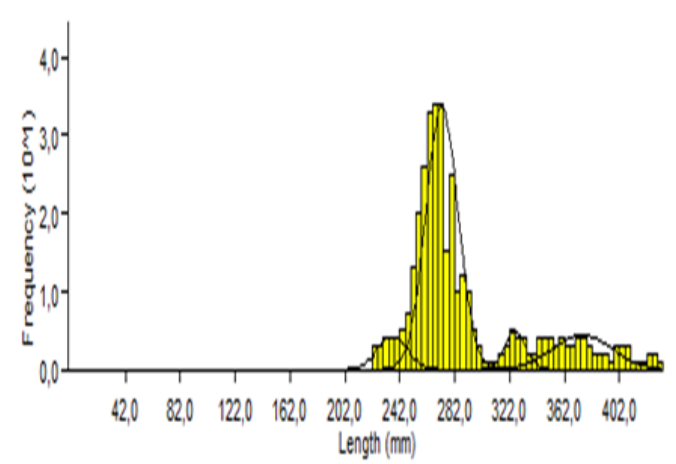

(a)

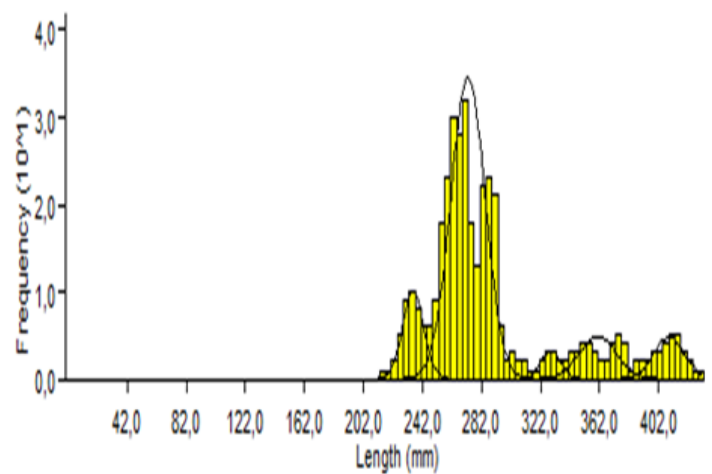

(b)

Figure 2: Graph of age group (cohort) of tuna (Euthynnus affinis) (a) male; and (b) female caught in the Western Waters of South Sulawesi in June - August 2019.

Table 1: Results of the analysis of the age group of tuna (Euthynnus affinis) caught in the Western waters of South Sulawesi by using Bhattacharya's method in June - August 2019.

\begin{tabular}{|c|c|c|c|}
\hline Sex & Average of Length & Total Individu & Separation Index \\
\hline Male & 236.67 & 27 & n.a \\
\cline { 2 - 4 } & 272.8 & 246 & 2.11 \\
\cline { 2 - 4 } & 326.04 & 22 & 2.24 \\
\cline { 2 - 4 } & 375.53 & 57 & 2.12 \\
\hline Female & 235.73 & 45 & na \\
\cline { 2 - 4 } & 272.86 & 251 & 2.15 \\
\cline { 2 - 4 } & 328.89 & 12 & 2.27 \\
\cline { 2 - 4 } & 360.89 & 37 & 2.08 \\
\cline { 2 - 4 } & 408.89 & 30 & 2.14 \\
\hline
\end{tabular}

Note: Separation index $=2$ can be separated into age groups

Table 1 shows that the highest number of male and female tuna was caught in $2^{\text {nd }}$ age group with the largest length in male tunas ranging from $272 \mathrm{~mm}$ to $275 \mathrm{~mm}$ and female tugas ranging from $271 \mathrm{~mm}$ to $274 \mathrm{~mm}$. In male tunas have average length of 272.80 with a population of 246 and in females have average length of 272.86 with a population of 251 . It is estimated that there was a pressure of caught in $2^{\text {nd }}$ age group.

Based on the separation of size groups of tuna as indicated in Table 1 that the separation index value between the size groups is more than 2. It indicates that the separation of size groups of tuna can be accepted by Bhattacharya's method. Separation index is a relevant quantity to the study if it is possible for successful separation of two adjacent components, if the separation index $<2$ then it is not possible to do separation between two size groups because of the overlap between groups of these sizes (Hasselblad, 1966; McNew \& Summerfelt, 1978; Clark, 1981; Sparre \& Venema, 1999).

\subsection{VON BERTALANFFY'S GROWTH MODEL}

The analysis results of growth parameters in asymptote length $(\mathrm{L} \infty)$, growth coefficient $(\mathrm{K})$, and theoretical age of fish at zero length $\left(\mathrm{t}_{0}\right)$ can be seen in Table 2 . 
Table 2: Estimating the growth parameters of tuna (Euthynnus affinis) based on Von Bertalanffy's model in the Western Waters of South Sulawesi in June - August 2019.

\begin{tabular}{|c|c|c|}
\hline \multirow{2}{*}{ Parameter } & \multicolumn{2}{|c|}{ Value } \\
\cline { 2 - 3 } & Male & Female \\
\hline $\mathrm{L} \infty(\mathrm{mm})$ & 455,00 & 453.50 \\
\hline $\mathrm{K}$ & 0.33 & 0.42 \\
\hline $\mathrm{t}_{0}$ & -0.2377 & -0.1853 \\
\hline
\end{tabular}

Note: $\mathrm{L} \infty$ (theoretical maximum length), $\mathrm{K}$ (growth coefficient, $\mathrm{t}_{0}$ (theoretical age at length is zero)

Based on Table 2 indicates the analysis results of parameters on male tuna, namely L $\infty=455.00 \mathrm{~mm}, \mathrm{~K}=0.33$ per year and $t_{0}=-0.24$ per year and parameters on female tuna, namely $L \infty=453.50 \mathrm{~mm}, \mathrm{~K}=0.42$ per year and $\mathrm{t}_{0}=$ -0.18 .

Based on the growth coefficient of tuna in Table 2 indicates that $\mathrm{K}$ in male and female tuna is smaller than 0.5. It indicated that growth in male and female tuna has slow growth. According to Sparre and Venema (1999) that the value of $\mathrm{K}<0.5$ has slow growth. Conversely, if the value of $\mathrm{K}>0.5$ has rapid growth.

The estimated value of the growth parameters that have been obtained $\left(\mathrm{L} \infty, \mathrm{K}\right.$ and $\left.\mathrm{t}_{0}\right)$ are entered into the Von Bertalannffy's growth equation, male tuna $\mathrm{Lt}=455.00\left(1-\mathrm{e}^{[-0.33(t+0.24)]}\right)$ and female tuna $\mathrm{Lt}=453.50\left(1-\mathrm{e}^{[-0.42(t+0.18)]}\right)$. Growth curves of male and female tuna are presented in Figure 2 by substituting various age levels into $t$ value.

The curve indicates that tuna will reach a theoretical maximum total length, namely in males at 455.00 and females at 453.50. It also shows that the growth rate of tuna is different each time and the growth rate of fish in the early phases of life experiences faster growth at a young age and is followed by slow growth in mature age until reaching the asymptote length where the fish do not grow anymore.
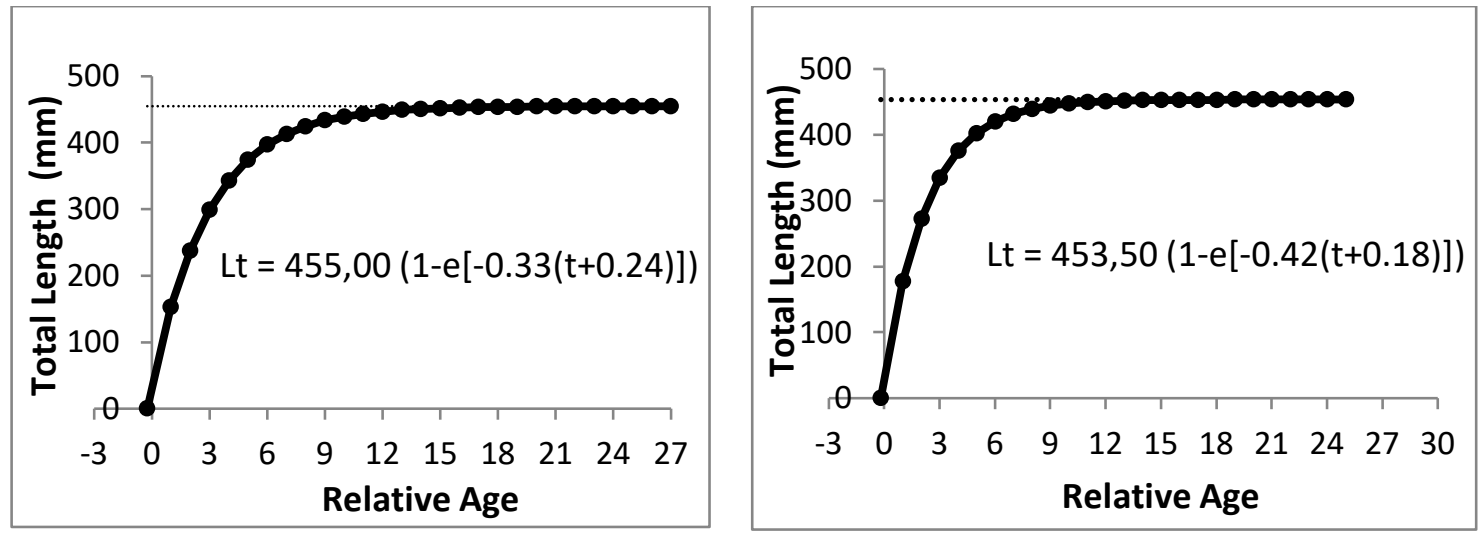

Figure 3: Growth curve of tuna (Euthynnus affinis) (a) male and (b) female caught in Western Waters of South Sulawesi in June - August 2019

It consistent with Effendie (2002) that rapid growth occurs in fish when they are 3-5 years. In mature fish, although growth continues but it slowly. In old fish the energy obtained from food is no longer used for growth, but only used for movement, replacing damaged cells and gonad maturity.

The results of Susilawati's et.al., (2013) study that conducted in Sunda waters have a maximum length (Lo) of $570.00 \mathrm{~mm}$, a growth rate coefficient $(\mathrm{K})$ of 0.34 per year and $t_{0}$ value of -0.264 per year where the value its growth is rather slow.

The difference of growth coefficient is due to differences in fishing environment and food abundance. The parameter $(\mathrm{K})$ is defined as a parameter that expresses the speed of the growth curve. Therefore, the higher of coefficient of growth, the faster of fish reach its maximum length.

The coefficient of growth rate $(\mathrm{K})$ will affect the maximum length of fish and this is likely due to several factors namely the amount and type of food, temperature, oxygen and water quality and environmental factors so that the organisms that live in it will have different shapes and sizes (Everthart and Yuono S, 1981). 


\subsection{MORTALITY AND EXPLOITATION RATE}

The analysis results obtained the estimated values of mortality and exploitation rate parameters of tuna in the Western Waters of South Sulawesi can be seen in Table 3 (Appendix 3).

Table 3: Mortality and exploitation rates of tuna (Euthynnus affinis) caught in West Waters of South Sulawesi in June - August 2019

\begin{tabular}{|c|c|c|}
\hline Mortality Rate & \multicolumn{2}{|c|}{ Value Per year } \\
\cline { 2 - 3 } & Male & Female \\
\hline Z & 1.12 & 1.35 \\
\hline M & 0.41 & 0.48 \\
\hline F & 0.71 & 0.87 \\
\hline E & 0.63 & 0.64 \\
\hline
\end{tabular}

Where: Z (Total Mortality), M (Natural Mortality), F (Catch Mortality), E (Exploitation).

Based on Table 3 shows that the male tuna has a catch mortality $(F)=0.71$, natural mortality $(\mathrm{M})=0.41$. In female fish has a catch mortality $(F)=0.87$ and natural mortality $(M)=0.48$. It shows that the mortality of tuna in the Western waters of South Sulawesi is more caused by fishing factors. The high of fishing mortality (F) is suspected to have an increasing number of fishing fleets each year. As the statistics of the Department of Maritime Affairs and Fisheries in Pinrang (2016), in 2014 (2.313 units), in 2015 (2.317 units), and in 2016 (2.355 units). This supports a large sizable fishing activity by fishermen every day continuously.

The results of research by Fayetri et.al., (2013) that tuna in the waters around Natuna, obtained a total mortality (Z) of 7.52 per year, natural mortality $(M)=2.413$ while the catching mortality rate $(F)=5.107$ per year and exploitation value $(\mathrm{E})=0.679$.

The results of Kusumawardana's et.al., (2013) research on male tuna on Sunda waters, obtained an estimated total mortality $(\mathrm{Z})$ of 1.11 per year, natural mortality $(\mathrm{M})=0.14$ and catch mortality $(\mathrm{M}) \mathrm{F})=0.97$ per year while in female tuna in the waters around Malacca strait, an estimated total mortality value $(\mathrm{Z})$ of 1.04 per year, natural mortality $(\mathrm{M})=0.15$, catch mortality rate $(\mathrm{F})=0.89$ per year and $\mathrm{E}=0.50$ per year.

Based on the value of exploitation rate (E) of tuna found in the Western Waters of South Sulawesi, it shows that tuna has been over-exploited. As known that the maximum rate of exploitation $(E)=0.5$, if it is greater than 0.5 then it is categorized as over-fishing (Gulland, 1983). The cause of the high rate of exploitation of tuna in the Western Waters of South Sulawesi is due to the ongoing fishing activities.

\subsection{YIELD PER RECRUITMENT}

Estimating relative yield per recruitment $\left(\mathrm{Y}^{\prime} / \mathrm{R}\right)$ is one of the models commonly used as a basis for fisheries management strategies (Gulland, 1983). ( $\mathrm{Y}^{\prime} / \mathrm{R}$ ) is estimated using Beverton and Holt's equations (Sparre and Vanema, 1999). The estimated results ( $\mathrm{Y}^{\prime} / \mathrm{R}$ ) of tuna in the Western Waters of South Sulawesi consisting of males of 0.0691 grams and in females of 0.0784 grams that can be taken part of the catch (Appendix 4) with exploitation rates exceeding 0.5 .

Thus, it can be said that the fishing of tuna has passed a sustainable value, and if catching is done continuously then tuna population will decrease even if it becomes extinct.

Motlagh et.al., (2010) shows that yield per recruitment of tuna in the coastal waters of Persian Gulf is $Y^{\prime} / R=$ 0.0620 .

\section{CONCLUSIONS AND SUGGESTIONS}

\subsection{CONCLUSION}

Based on the results of the study can be concluded as follows:

1) Age group of male tuna has 4 cohorts and the female has 5 cohorts. 
Population Dynamics of Tuna (Euthynnus Affinis, Cantor 1849) in Western Waters of South Sulawesi

2) Asymptote length ( $\mathrm{L} \infty)$ of male tuna can reach a size of $455.00 \mathrm{~mm}$ with a growth rate of $\mathrm{K}=0.33$ per year and $t_{0}=-0.2377$ per year, whereas in female tuna $(\mathrm{L} \infty)$ can reach $453.50 \mathrm{~mm}$ with a growth rate of $\mathrm{K}=0.42$ per year and $\mathrm{t}_{0}=-0.1853$ per year. This value indicates a slow growth rate.

3) Mortality value in male tuna is natural mortality $(\mathrm{M})=0.41$ and catch mortality $(\mathrm{F})=0.71$, while mortality value for female tuna is natural mortality $(\mathrm{M})=0.48$ and catch mortality $(\mathrm{F})=0.87$ and the exploitation value (E) of male tuna is 0.63 per year and female tuna is 0.64 .

4) Yield per recruitment relative of male tuna is 0.0691 gram and in female is 0.0784 gram.

\subsection{SUGGESTIONS}

For further research on tuna population dynamics it is recommended can be related to biological aspects, especially the level of gonad maturity, the mature size of the first gonad, spawning patterns and seasons, and the relationship of the environment and its habitat. In addition, it is necessary to observe the dynamics of tuna population for one year. So that information can be used in formulating resource management efforts to remain sustainable.

\section{SOURCES OF FUNDING}

This research received no specific grant from any funding agency in the public, commercial, or not-for-profit sectors.

\section{CONFLICT OF INTEREST}

The author have declared that no competing interests exist.

\section{ACKNOWLEDGMENT}

Acknowledgments the authors convey to all parties who have given research permission, assistance, support and guidance to the authors including to:

1) Regent of District and Head of Department of Maritime Affairs/Fisheries in Pinrang regency.

2) Dr. Ir. St. Aisjah Fachrum, M.Sc., as the Dean of the Faculty of Marine and Fisheries Sciences, Hasanuddin University.

\section{REFERENCES}

[1] Badan Meteorologi, Klimatologi \& Geofisika (BMKG). 2017. Data Statistik Suhu Perairan Kota Makassar, Sulawesi Selatan.

[2] Dinas Perikanan dan Kelautan, 2016. Laporan Statistik Perikanan Kabupaten Pinrang. Dinas Perikanan dan Kelautan Kabupaten Pinrang. Makassar

[3] Effendie, M.I. 2002. Biologi Perikanan. Yayasan Pustaka Nusantara. Yogyakarta.

[4] Everhart, W. H. A. W. Eipper and W. D. Youngs. 1975. Principle of Fishery Science Coemell Univ. Pres

[5] Fayetri, W. R., T. Efrizal dan A. Zulfikar. 2013. Kajian Analitik Stok Ikan Tongkol (Euthynnus affinis) Berbasis Data Panjang Berat Yang Didaratkan di Temat Pendaratan Ikan Pasar Sedanau Kabupaten Natuna. Program Studi Manajemen Sumberdaya Perairan. Fakultas Ilmu Kelautan dan Perikanan. Universitas Maritim Raja Ali Haji. Tanjung Pinang

[6] Gulland JA. 1969. Manual of Methods for Fish Stock Assessment, Part Fish Population Analysis. FAO. Rome, Italy. $154 \mathrm{p}$

[7] Kusumawardani, N, M., Achmad, F dan Mennofatria, B. 2013. Kajian Stok Sumber Daya Ikan Tongkol (Euthynnus affinis) di Perairan Selat Sunda yang Didaratkan di Pelabuhan Perikanan Pantai Labuan, Pandeglang, Banten. Prosiding Seminar Nasional Ikan ke 8. Departemen Manajemen Sumber Daya Perairan. Fakultas Perikanan dan Ilmu Kelautan. Institut Pertanian Bogor. Bogor. 
[8] Motlagh. S. A. T., Hashemi. S. A dan Kochanian. P. 2010. Population Biology and Assessment of Kawakawa (Euthynnus affinis) in Coastal Waters of the Persian Gulf and Sea of Oman (Hormozgan Province). Iranian Journal of Fisheries Sciences. Volumen 9 Nomor 2. Hal: 315 - 326.

[9] Pauly, D. 1983. A. Selection of Sample Method for Assessment Tropical Fish Stock. Fao Fish Tech. New York.

[10] Sari, H. 2013. Pendugaan Beberapa Parameter Dinamika Populasi Ikan Layang (Decapterus macrosoma) di Perairan Teluk Bone, Sulawesi Selatan. Universitas Hasanuddin. Makassar.

[11] Sparre \& Venema S. C. 1999. Introduksi Pengkajian Stok Ikan Tropis, Buku I: Manual. Pusat Penelitian dan Pengembangan Perikanan, Badan Penelitian dan Pengembangan Pertanian. Penerjemah. Jakarta (ID): Pusat Penelitian dan Pengembanagan Perikanan, Badan Penelitian dan Pengembangan Pertanian. Terj. dari: Introduction to Tropical Fish Stock Assessment, Part I: Manual.

[12] Susilawati., T, Efrizal dan Andi, Z. Kajian Stok Ikan Tongkol (Euthynnus affinis) Berbasis Panjang Berat yang Didaratkan di Pasar Ikan Tarempa Kecamatan Siantan Kabupaten Kepulauan Anambas. Program Studi Manajemen Sumberdaya Perairan. Fakultas Ilmu Kelautan dan Perikanan. Universitas Maritim Raja Ali. 